\title{
Hereditary Hemolytic Anemia
}

National Cancer Institute

\section{Source}

National Cancer Institute. Hereditary Hemolytic Anemia. NCI Thesaurus. Code C34379.

A congenital hemolytic anemia caused by defects of the erythrocyte membrane, enzyme deficiencies, or hemoglobinopathies. 